\title{
病院におけるシーツ，看護衣の細菌污染と その防止について
}

\author{
高 峰 道 子*1・古 瀬 浩 介*2

\section{Bactelial Contamination of Laundly in Hospital: Actual State of the Contamination and Preventive Measures Against it}

\author{
Michiko Takamine*1 and Kohsuke Furuse*2 \\ *1 Tokyoto Saiseikai Mukoujima Hospital \\ ${ }^{* 2}$ Deparment of Biology, Shimane Medical University
}

\section{はじめに}

院内感染防止のために, これまで用いられて きた方法は，診断に基づいた疾患別の隔離を行 らといらものであった.

しかしながら，臨床症状が明らかでない場合 や，感染の有無そのものが不明の場合には，こ のシステムはうまく機能しない。臨床症状が現 れていないHIVやHBVなどのウイルス感染の例 で明らかなよらに，血液や体液などのbody substance は潜在的な感染源であると考えるべ きである.このようなbody substanceから体 を守るために，ラテックス製グローブなどの物 理的バリヤーを使用する “body substance isolaion システム”が提唱され，実行されるようになっ てきた ${ }^{1,2)}$.

しかしながら, body substanceからの直接 的な感染を防止するだけでなく，患者及び看護 者が共に接触するリネン類一それらは常にbody substance 污染される可能性がある一を介し ての間接的な污染を防ぐ必要があり，そのため にはより幅広い院内環境の整備, リネン類の消 毒, 手洗いなどの感染予防法の励行が必要であ る.
ここでは, 院内感染の媒体として大きな位置 を占めるシーツ, 看護衣, タオルなどのリネン 類に絞って，(1)細菌数の測定法，(2)細菌污染の 実態，(3)污染に影響を及ぼす要因，を概観する と共に, 污染に影響を及ぼす要因の一つとして 我国で広く使用されている洗濯糊に関する著者 らの調査, 実験を述べ污染防止について考察し たい.

\section{（1）リネン類の細菌数測定法}

リネン類の細菌污染度を調べる場合, 最も重 要な点はその方法が定量性に優れていることで ある. Cody ら ${ }^{3)}$ はリネン類全体の細菌污染度 を調べる方法を検討した。すなわち, 既知濃度 の大腸菌あるいは黄色ブドウ球菌を接種したリ ネン類からの細菌回収率を 3 種の方法—(1)振盪 法(細菌を接種した布を緩衝液中で振盪し, 振 盪液をフィルターで瀘過して細菌を回収し, 生 菌数を測定する), (2)ブレンダー法(細菌を接種 した布をハサミで小さく裁断し，緩衝液中でブ レンダーで高速攪拌した後攪拌液をフィルター で瀘過して細菌を回収し，生菌数を測定する), (3)寒天重層法(細菌を接種した布を隇菌プラス チックシャーレに入れ, その上に寒天培地を重

*1 東京都済生会向島病院 $\quad * 2$ 島根医科大学 
層して，生菌数を測定する)一で検討し，(2)の ブレンダー法は回収率は高いが操作が繁雑であ ク, (3)の寒天重層法は回収率が悪く, 結局, 細 菌の回収率と使いやすさの面から，(1)の振温法 が最も良いと報告している. (3)の寒天重層法で は, 布の表面の細菌しか測定できないので回収 率が悪いのは当然である.

この振盪法は，洗濯による污染除去効果を調 ベる場合のように，リネン類の表面だけでなく 繊維内部も含めた総菌数を測定する必要がある 場合に適しているといえる.

一方, リネン類の表面の細菌污染度を調べる 方法の一つとして広く行われている方法にスタ ンプ法がある。これは，リネン類の表面に寒天 平板培地を圧着して得られるコロニー数を調べ るものであるが，簡便性，経済性から良く用い られる方法であり ${ }^{4)}$, 病室においてシーツの污 染を経時的に調べる場合や，衣類など日常接触 するものの表面の污染が問題になる場合に用い られる.ただし，このスタンプ法はリネン表面 のコロニー数を測定するだけであって, 総菌数 を求めるものではない点に注意する必要がある.

つまり，リネンをブレンダー法あるいは振盪法 で調べればスタンプ法よりも相当多くのコロニー 数が検出されるだろう．というのは 1 個のコロ ニーに含まれる菌数は莫大であり, 仮にコロニー の大きさによて $10^{2} \sim 10^{5} \mathrm{CFU}$ (Colony Forming Unit)/コロニーとすると, 総菌数は $10^{3} \sim 10^{6}$ CFUにも達するからである. 振盪法よりもブ レンダー法の方が回収率が高いのは, 激しい摫 拌によってコロニーがより細かく分離されるた めであろら、いずれにしても, 総菌数を測定す る必要があるか, あるいは, 表面沫染を測定す る必要があるかによって両者を使い分けるべき である。

\section{（2）看護衣，シーツなどの細菌污染の実態}

看護者から患者へのブドウ球菌の伝播は手を 介して起こることが示されている5). また新生 児においては, 污染度の高い毛布, 衣類, オム ツなどを介してブドウ球菌が伝播されることが 報告されている6).

Hambraeus ${ }^{7)}$ はヤケド患者病室における看
護衣の細菌污染度および看護衣を介しての黄色 ブドウ球菌の病室間移動について調査し, 以下 のように報告している。な招，細菌数の測定は 総菌数を測定する振盪法一衣類を $1 \%$ ペプトン 水で振盪し, 振盪液をフィルターで瀘過して, 細菌を回収する一を用いている.

（a）ヤケド患者用病室で通常の勤務について いる看護婦の看護衣およびその上に着用してい る予防衣あたりの黄色ブドウ球菌量は，28検体 を調べて，それぞれ $1.4 \times 10^{3} \mathrm{CFU} /$ 看護衣と 3.0 $\times 10^{4} \mathrm{CFU} /$ 予防衣とかなり高く, それらの菌 株はファージ・タイピングによって患者由来の ものが多いことが明らかになった（b) 黄色ブ ドウ球菌で污染された室内での看護衣の污染度 は，予防衣を着用しなかった場合には，着用し た場合の $8 \sim 25$ 倍も高かった. (c) 予防衣を着 用することによって，移動した病室内 (空気中) への細菌の持ち込みは, $1 / 4 \sim 1 / 10$ に減少し, 患者の着衣㐨よびシーツへの污染は $1 / 100$ に減 少した。これは, ヤケド患者を看護する際, 患 者からの看護衣への直接的な污染が予防衣によっ て阻止されるためと考えられる. (d) 污染度の 高い看護衣の上に予防衣を着用した場合には, 污染防止効果は認められなかった。 これは, 看 護衣と予防衣の摩擦によって細菌が付着した微 細な繊維などが遊離するためと考えられる。

Weinstein $5^{8)}$ は一般病室抢よび隔離病室で 使用されたリネン類の表面の細菌（黄色ブドウ 球菌とグラム陰性桿菌) 污染度をスタンプ法で 調べた結果, 両者間に有意差が認められなかっ たことから, 隔離病室からのリネン類を熱可溶 性のポリビニールアルコールバッグに入れ，そ れを運搬用のバッグに入れるいわゆる二重バッ グ法で洗濰室に運ぶ必要はないと述べている. ただし，問題は熱可溶性バッグを使用しなくて もよいといら経済上の点にあるのではなく, 患 者および病院で働く人の感染を防止するために は，むしろすべてのbody substance およびそ の付着物が潜在的な感染源であるという認識に 基づいて,

（a）リネン類取扱い者は，グローブを着用し， 確実な手洗いを励行する.

（b）患者のベッドサイドで，周囲を污染しない 
ようにすべてのリネン類をバッグに確実に収納 する.

（c）情況に応じて予防衣，プラスチックエプロ ン，マスク，ゴーグルを着用する.

ことを推奨している.

一般に, 洗濯によって污れが落とされるだけ でなく, 細菌污染もなくなると信じられている. そこで， Nicholes ${ }^{9)}$ は，一般のランドリーで洗 濯された繊維製品(ユニホーム，ナプキン， タ オルなど)の細菌污染度を調查し, 次のように 報告している.

(a)リネン類の細菌污染度の測定において寒天 平板培地を用いるスタンプ法で求めた值とブレ ンダー法で測定した值とは全く相関しなかった。

(b) 洗濯済みのリネン類の細菌数をブレンダー 法一リネン類を直径 1 インチの円形に切抜き, $200 \mathrm{ml}$ の滅菌水中でブレンダーで高速攪找して その液中の菌数を調べる一で計測した場合，ス タンプ法では検出されなかった検体から大量の 細菌 $\left(10^{2} \sim 10^{7} \mathrm{CFU} /\right.$ 平方インチ)が検出された.

(c) 洗剂の種類, 洗濯時間, 温度を調節するこ とによって, リネン類の細菌数を大幅に減少さ せさることができ(従来通りの方法で洗滥した 場合の残存菌数： $4 \times 10^{4} \mathrm{CFU} /$ 平方インチ, 改良法の場合の菌数：<32 CFU/平方インチ), その際, 塩素系よりも酸素系の漂白剂の方が約 20倍消毒効果が高かった。

さらに, Christian ら ${ }^{10)}$ は病院内のランドリー 施設による洗濯によって，污染細菌を有効に除 去でさるかどらかを検討している．細菌数の測 定は総菌数を測定するブレンター法によってい る.

(a) 洗䍜前の使用済みリネン類(約100検体)の ブドウ球菌および大腸菌群による污染度は $<0.1$ 〜> $4 \times 10^{3} \mathrm{CFU} / \mathrm{cm}^{2}$ であった.

(b) これらの污染されたリネン類の細菌数は, 病院内ランドリーにおける通常の洗濯 (洗剤処 理 $($ 第 1 回 $) \rightarrow$ 漂白剂処理 $\rightarrow$ 洗剂処理 $($ 第 2 回 $) \rightarrow$ 中和剤処理 $\rightarrow$ 軟化剂処理, 洗滌温度 $\left.75^{\circ} \mathrm{C}\right)$ によっ て $1 \mathrm{CFU} / \mathrm{cm}^{2}$ 以下に減少したが，同じ条件下， 洗滌温度だけを低くした場合 $\left(48 \sim 60^{\circ} \mathrm{C}\right)$ にも高 温時と同程度の除菌効果が認められた.

(c) 漂白剂の殺菌効果は濃度を上げることによっ
て高められた。

これらの報告は，適切な洗濯法を用いること によって，実際に使用され污染されたリネン類 から細菌を除去することができることを示して いる。なお， Robintonら ${ }^{11)}$ は布製タオルとペー パータオルの表面の細菌污染度をスタンプ法に よって調査し，布製よりもペーパータオルの方 が污染が少ないことを認め, 衛生面からペーパー タオルを推奨している.

一方, Wiksell ら ${ }^{12)}$ は予め一定量の細菌を接 種したシーツ(綿50\%とポリエステル $50 \%$ 混紡) 上での細菌の残存率に対する洗濯時の液温, 洗 剤の種類, 洗滌サイクルなどの影響を調べた. 菌数の測定は総菌数を求める振燙法によってい る.

(a) 霊菌は液温 $57^{\circ} \mathrm{C}$ 以上では生残菌は認められ なかった(洗濯前の菌数 : $1.6 \times 10^{5} \mathrm{CFU} / \mathrm{cm}^{2}$, 洗濯後 : $\left.<10 \mathrm{CFU} / \mathrm{cm}^{2}\right)$ が, 黄色ブドウ球菌 は $68^{\circ} \mathrm{C}$ でもある程度生残菌が認められた(洗濯 前の菌数 : $3.2 \times 10^{5} \mathrm{CFU} / \mathrm{cm}^{2}$, 洗濯後 : $1.6 \times 10$ $\mathrm{CFU} / \mathrm{cm}^{2}$ ). 耐熱菌である Bacillus stearothermophilus は $68{ }^{\circ} \mathrm{C}$ でもあまり大きな影響を受けなかっ た (洗濯前の菌数 : $5.0 \times 10^{4} \mathrm{CFU} / \mathrm{cm}^{2}$, 洗濯後 : $\left.1.0 \times 10^{3} \mathrm{CFU} / \mathrm{cm}^{2}\right)$.

これは，ここで用いた洗濯法によってはリネ ン類に付着した菌の除去は不完全であることを 示している.

（b）これらの細菌は，洗䍜の過程で他のシーツ を污染することが示された. したがって，污染 されている可能性のあるリネン類は別個に取り 扱った方がよい。

(c) 洗剂の種類を変えても細菌の残存率に影響 はなかった。

ただし，この実験では漂白剤を使用していな いのでその殺菌効果を確かめる必要がある。い ずれにしても効果のある洗濯法を確立するため には，既知濃度の細菌を接種した布を用いて， 水流(水のみの場合と洗剂を含む場合)による物 理的な除菌効果と，洗剤昼よび漂白剂の殺菌効 果を分けて測定する必要がある.

\section{（3）リネン類の細菌污染に影響を与える要因}

Wilkoff ら ${ }^{13)}$ はリネン上での黄色ブドウ球 
菌の安定性に影響する要因として，接種法と接 種されたリネン類の保管条件を検討した.

各種リネン類に 3 種類の方法一(1)菌液を直接 接種する液体法, (2)チャンバー内でエアロゾル を噴霧するエアロゾル法, (3)広口ビン内で涷結 乾燥菌と微細繊維の混合物と接触させるダスト 法一で接種した黄色ブドウ球菌の生残菌数を 20 週にわたって追跡調査した. 菌数の測定は布を 八サミで細かく裁断し，生理食塩水中でホモジ ナイザーで攪拌して総菌数を求めるブレンダー 法によっている.

（a）いずれの接種法においても，菌を接種した 布を相対湿度 $35 \%$, 温度 $25^{\circ} \mathrm{C}$ に保った場合の方 が，湿度 $78 \%$ ，温度 $25^{\circ} \mathrm{C}$ に保った場合よりも生 残率は有意に高かった。

（b）湿度 $35 \%$, 温度 $25^{\circ} \mathrm{C}$ に保った場合，(1)の液 体法で直接接種した時 (接種直後の菌数 $: 10^{7}$ $\mathrm{CFU} /$ 平方インチ, 1 日後の菌数: $<10^{2} \mathrm{CFU} /$ 平方インチ)よりも, (3)のダスト法(接種直後: $10^{8}$ $\mathrm{CFU} /$ 平方インチ, 7 日後: $10^{4} \mathrm{CFU} /$ 平方イン チ), (2)のエアロゾル法 (接種直後 : $10^{8} \mathrm{CFU} /$ 平方インチ, 7 日後 : $10^{3} \mathrm{CFU} /$ 平方インチ)で 接種した時の方が生残率ははるかに高かった。

これらの結果は, 低湿度下の病室内で污染さ れたリネン類から黄色ブドウ球菌が付着した繊 維ダストが遊離した場合，他のリネン類を污染 する危険性が高いことを示唆している.

このようにリネン類の細菌污染に影響を与え る要因として, 洗濯法9,10,12), 污染ルート, 温 度, 湿度, 布の材質 ${ }^{13)}$ などは調べられている が，わが国の病院で広く使用されている洗灌糊 (コーン・スターチ)の影響を調査した報告は見 当たらない。

そこで我々は，病院に抒けるシーツ，看護衣 の細菌污染の実態を調査するとともに，ブドウ 球菌の増殖性, 安定性に対するコーン・スター チの影響について, in vitroの接種実験を行っ た 14,15,16, 26).

シーツ, 看護衣の細菌污染度の測定は, 普通 寒天平板培地を用いるスタンプ法によった。

(a) 細菌によるシーツ污染の経日的変化を調べ たところ，ベッド上生活患者のシーツの污染度 は, 通常の生活を営んでいる看護学生のシーツ
の污染度よりも有意に高く, シーツ交換後の 1 , 4，7 日目之順次増大していた。 また，シーツ の部位別では, 繁部の污染度が最も高く, つい で頭部，足部の順であった.

（b）尿失禁のために途中でシーツ交換した場合， 交換 1 日目から通常の交換時よらも污染度が高 く，その後も急激にコロニー数が増加する傾向 が認められた。

(c) 看護衣の場合，1日後のコロニー数は糊づ け布の方が有意に高い值を示した.

（d）シーツ，看護衣から分離される菌の70９0 \%は表皮ブドウ球菌であった. 黄色ブドウ球菌 ( $4 \sim 7 \%)$ )，グラム陰性桿菌（1３\%）も認めら れた。

（e）そこで，糊づけがブドウ球菌に与える影響 をin vitroの接種実験によって検討した結果, コーン・スターチが綿布上での表皮ブドウ球菌, 黄色ブドウ球菌㧍よびメチシリン耐性黄色ブド ウ球菌 (MRSA)の増殖性, 安定化に役立つこ とが示された。なお，ブドウ球菌は，通常はス ターチを分解しないとされているが，Difco 社 のsoluble starch を用いて糖分解能とコロニー 形成能を調べた結果，いずれもある程度スター チを利用することが示された。

以上の結果から, 病院内ベッド上生活者のシー ツの場合，1日目から污染度が高いのはその時 までてにすでに身体，寝衣などに付着している 菌が，その屯ま新しいシーツに持ち越されるた めと考えられる，さらにシーツに付着した菌は， コーン・スターチ, 患者の体温と汗による湿気 などが合わさって，日ごとに増殖し污染度を高 くしていると考光られる。 また，尿失禁のため にシーツ交換した場合, 失禁の際に横シーツだ けを換光，ゴム横シーツを換えないことが多く， その場合, 糊のついた新しい横シーツにゴム横 シーツに残っている尿の成分と湿気が加わり， 細菌増殖の好条件をつくり出していると考兄ら れる。

これらの結果から, シーツや看護衣の細菌污 染をできる限り少なくするために，糊剂として のコーン・スターチの使用を中止する必要があ ると考えられる。 
文 献

1) Lynch, P., M.M. Jackson, M.J. Cummings, and W.E. Stamm: Rethinking the role of isolation practices in the prevention of nosocomial infections. Ann. Intern. Med., 107, 243-246, 1987.

2 ) Mcpherson, D.C. , and M.M. Jackson: Isolation precautions for a changing environment $\cdots$ a new approach. J. healthcare materiel management, 5, 28-32, 1987.

3 ) Cody, H.J., P.F.Smith, M.J. Blaser, F.M. LaForce, and Wen-Lan L. : Comparison of methods for recovery of Escherichia coli and Staphylococcus aureus from seeded laundry fabrics. Appl. Environ. Microbiol., 47, 965-970, 1984.

4) Rubbo, S.D., and S. Dixon: A contact-plate technique for determining bacterial contamination of fabrics. Lancet 2, 394-397, 1960.

5 ) Mortimer, E.A.Jr., P.J. Lipsitz, E. Wolinsky, A.J. Gonzaga, and C.H. Rammelkamp, Jr.: Transmisson of staphylococci between newborns: Importance of hands of personel. Amer. J. Dis. Child., 104, 289295, 1962.

6 ) Gonzaga, A.J., E.A. Mortimer, Jr., E. Wolinsky, and C.H. Rammelkamp: Transmissin of staphylococci by fomites. JAMA 189, 711-715, 1964.

7 ) Hambraeus, A.: Transfer of staphylococcus aureus via nurses' uniforms. J. Hyg. Camb. 71, 799-814, 1973.

8 ) Weinstein, S.A., N.M. Gantz, C. Pelletier, and D. Hibert: Bacterial surface contamination of patients' linen: Isolation precautions versus standard care. Am. J. Infect. Cont. 17, 264-267, 1989.

9 ) Nicholes, P.S. : Bacteria in laundered fabrics. Am. J. Public Health. 60, 2175-2180, 1970.

10) Christian, R.R., J.T. Manchester, and M.T. Mellor: Bacteriological quality of fabrics washed at lower-than-standerd temper- atures in a hospital laundry facility. Appl. Environ. Microbiol. 45, 591-597, 1983.

11) Robinton, E.D. , and E.W. Mood: A study of bacterial contaminants of cloth and paper towels. Am. J. Public Health. 58, 14521459, 1968.

12) Wiksell, J.C., M.S. Pickett, and P.A. Hartman: Survival of microorganisms in laundered polyester-cotton sheeting. Appl. Microbiol. 25, 431-435, 1973.

13) Wilkoff, L.J., L. Westbrook, and G.J. Dixon: Factors affecting the persistence of Staphylococcus aureus on fabrics. Appl. Microbiol. 17, 268-274, 1969.

14）遠藤真由美, 高峰道子：ベッド上生活患者 のシーツの污染度一細菌学的検討一, 看護 学雑誌, 53 (10), 981-987, 1989.

15）石川美恵, 高峰道子 : 看護衣の交換と污染 度の実態, 看護学雑誌, 53 (10), 988-993, 1989 .

16）高峰道子, 古瀬浩介：シーツ及び看護衣に 使用する洗灌糊の細菌污染への影響一in vitro の実験結果から一, 第10回日本看護科学学 会発表 1990.12 (日本看護科学会誌, 10 (3), 136-137, 1990).

17）高橋景子：シーツの污染度一細菌学的検討, 看護研究集録, 神奈川県立看護教育大学校, 看護教育学科, 19-26, 1980.

18）川名林治, 馬越キヨ, 内藤サダ : 院内感染 の今日的様相とその防止対策の実際, ナー スステーション, $17(1), 12-23,1977$.

19）八下ユリ子：院内感染防止のための管理体 制一その実情と問題点, ナースステーショ ン, 17 (1), 29-33, 1977.

20）神木照雄：感染症に対するNursing Care の在り方についてのひとつの考察, 看護技 術, 17 (7), 22-32, 1971.

21）越川良江, 殖栗千代子, 小林章男：病院環 境の污染状況について, 臨床看護, 5, 124128, 1979.

22）萩沢さつえ：ベッドブラシ清掃についての 細菌学的検討, 看護展望, 4 (2), 32-39, 1979.

23）林 滋子：感染防止のための環境整備とナー 
スの役割，看護技術，17（1）, 16-21，1971.

24）宮田文代子：院内感染と看護業務, ナース ステーション, 1 (1), 34-43, 1977.

25) Holt, J.G., ed. : Bergey's manual of systemic bacteriology , 2, 1015-1035, 1986, Williams \& Wilkins, Baltimore, U.S.A.
26) Takamine, M., K. Furuse, R. Tatewaki, J. Endo, and T. Ezaki: Effects of laundry starch on the viability of staphylococci on cotton sheets. First International Nursing Research Conference, 1992, 10 (PROCEEDINGS 176, 1992. 10). 